\title{
Biochemical characterization of preovulatory and cystic ovarian follicular fluid of sow
}

\author{
R. Nath ${ }^{1}$, N. Mahanta ${ }^{2}$, M. Islam ${ }^{3}$ and S. S. Deka ${ }^{1}$
}

1. Department of Veterinary Biochemistry, College of Veterinary Science, Guwahati, Assam, India; 2. Department of Animal Reproduction, Gynaecology and Obstetrics, College of Veterinary Science, Guwahati, Assam, India; 3. Department of Veterinary Pathology, College of Veterinary Science, Guwahati, Assam, India.

Corresponding author: Rita Nath, e-mail: ritasankr@rediffmail.com, NM: nipendramahanta@gmail.com, MI: muzaharulislam@gmail.com, SSD: surakshasubedi@gmail.com

Received: 01-07-2014, Revised: 29-09-2014, Accepted: 04-10-2014, Published online: 31-10-2014

doi: 10.14202/vetworld.2014.895-898. How to cite this article: Nath R, Mahanta N, Islam M, Deka SS (2014) Biochemical characterization of preovulatory and cystic ovarian follicular fluid of sow, Veterinary World 7(10): 895-898.

\begin{abstract}
Aim: The present study was designed to biochemically characterize ovarian cyst follicular fluid of sows and to relate possible changes in relation to preovulatory ovarian follicular fluid of sows.

Materials and Methods: Ovaries were collected from adult and non-pregnant slaughtered sow (Hampshire X local cross). A total of 16 pairs of ovaries were investigated, and they were classified according to their pathological and physiological status into two categories i.e. preovulatory and cystic follicle (diameter $>25 \mathrm{~mm}$ with turbid appearance). Fluid was aspirated from the follicles and stored at $-20^{\circ} \mathrm{C}$ prior to assaying. Follicular fluid samples were analyzed for glucose, total protein, cholesterol, triglycerides, blood urea nitrogen (BUN), urea, creatinine, uric acid. The activities of the enzymes aspartate transaminase, alanine transaminase (ALT), alkaline phosphatase (ALP), creatine kinase (CK) and gamma-glutamyl transpeptidase (GGT) were also estimated by spectrophotometric methods. The data were statistically analyzed using the SPSS software.

Results: As follicles became cystic, the concentrations of glucose, cholesterol, triglyceride, total protein and albumin showed a significant $(\mathrm{p}<0.05)$ increased while BUN decreased significantly $(\mathrm{p}<0.05)$. The enzyme activities of ALT, ALP and CK increased significantly $(\mathrm{p}<0.05)$, but the activity of GGT significantly $(\mathrm{p}<0.05)$ decreased.
\end{abstract}

Conclusion: Results obtained showed that there was a significant change in most of the cystic follicular fluid metabolites.

Keywords: biochemical characterization, follicular fluid, sows.

\section{Introduction}

Ovarian follicular cyst is an important reproductive pathology. It is generally accepted that cystic ovary develop from preovulatory follicles that fail to ovulate, persist in the ovary and interfere with the normal function of the ovary [1]. Cystic ovarian follicles (COF) are defined as follicular structure $>20 \mathrm{~mm}$ in diameter, persisting for more than 6 days with no corpus luteum detectable by ultrasound and clearly interfering with the normal ovarian cyclicity. The development of COF is associated with different predisposing factors, leading to negative energy balance, but the exact mechanism is still not clear. The most important role in the pathogenesis of COF is the lack of a pre-ovulatory luteinizing hormone ( $\mathrm{LH}$ ) surge, insufficient in LH magnitude or LH surge at the wrong time during dominant follicle maturation. Follicular fluid contains a number of biochemical metabolites derived from the serum or produced within the follicle and is associated with the metabolic activity of follicular cells [2]. Previous studies in several mammalian species clearly indicated that follicular fluid contains essential substances that are required for oocyte

Copyright: The authors. This article is an open access article licensed under the terms of the Creative Commons Attributin License (http:// creative commons.org/licenses/by/2.0) which permits unrestricted use, distribution and reproduction in any medium, provided the work is properly cited. maturation and its fertilization. Changes in biochemical metabolites in the follicular fluid may influence oocyte maturation and quality [3].

Since very scarce literature is available on biochemical metabolites of cystic follicular fluid of sow and thus the study was undertaken to compare the biochemical constituents of cystic and preovulatory ovarian follicular fluid of sow.

\section{Materials and Methods}

\section{Ethical approval}

The prior approval from the Institutional Animal Ethical Committee was obtained for collection of the cysts after slaughter of the sows for the present study.

\section{Collection of ovaries}

Ten pairs of ovaries with regressed corpus lutea and preovulatory follicle were collected from normal cyclic and non-pregnant sows (Hampshire X local cross) as well as six pairs of cystic ovaries from a local abattoir and the ovaries were excised immediately after slaughter and transported to the laboratory in $0.9 \%$ chilled $\left(4^{\circ} \mathrm{C}\right)$ normal saline within $1 \mathrm{~h}$ after slaughter. Breeding history of the animals was not known.

\section{Collection of follicular fluid}

In the laboratory, the ovaries were washed twice in chilled normal saline. Each ovary was cleaned of 
the extraneous tissue, and follicular fluid was aspirated by puncturing the follicles and holding them in forceps using a 22-gauge needle attached to a $5 \mathrm{ml}$ plastic syringe. During the process of follicle aspiration, the ovaries remained in a glass beaker $(1000 \mathrm{~mL})$ immersed in saline solution $\left(4^{\circ} \mathrm{C}\right)$. Ovary were classified according to their pathological and physiological status into two groups i.e. preovulatory follicle of diameter of 15-20 mm (Group I) and cystic follicle of diameter $>25 \mathrm{~mm}$ (Group II) with turbid appearance. Only a portion of the fluid was collected by applying syringe pressure to avoid additional traumatization of the follicles. This process was performed as soon as possible to avoid degenerative changes. The follicular fluid was made cell-free by centrifuging at $5000 \mathrm{rpm}$ for $30 \mathrm{~min}$ [4]. The follicular fluid was then filtered through a $0.2 \mathrm{~mm}$ filter (Whatman, Mumbai, India) to make sure that no sediment is found in the supernatant while transferring it. The aliquots of follicular fluid were kept in a $5 \mathrm{ml}$ tube (Tarsons, Kolkata, India) and stored in a deep freezer $\left(-20^{\circ} \mathrm{C}\right)$ for biochemical analysis. The time elapsed from animal slaughter to follicular fluid recovery did not exceed $4 \mathrm{~h}$. Enzyme activities were estimated in freshly collected follicular fluid.

\section{Biochemical analysis of the follicular fluid}

Follicular fluid samples were analyzed for various biochemical variables. The concentrations of glucose, cholesterol, triglycerides, total proteins, albumin, globulin, A:G ratio, urea, blood urea nitrogen (BUN), uric acid and creatinine and activities of the enzymes aspartate transaminase, alanine transaminase (ALT), alkaline phosphatase (ALP), creatine kinase (CK) and gamma-glutamyl transpeptidase (GGT) were estimated spectrophotometrically by Systronic 20 using commercially available kits by procedures as recommended by the manufacturer of kits as followed by Nath et al. [5]. After processing the samples and standards provided with the kits, absorbance of the standard and the samples was determined. Concentration of the biochemical constituents was calculated according to the manufacturer instruction.

\section{Statistical analysis}

Mean values ( \pm standard error $[\mathrm{SE}]$ ) for the concentrations of various biochemical metabolites was calculated for follicular fluid in the two groups of animals. The data were statistically analyzed using the SPSS software (SSPS South Asia Pvt. Ltd., Kacharakanahalli, Bangalore-560043, Karnataka, India).

\section{Results}

The mean values $( \pm \mathrm{SE})$ of various biochemical metabolites and enzyme activities of follicular fluid of sow are presented in Tables-1 and 2, respectively. The cystic ovary of pig is shown in Figure-1. From the study, it was seen that total protein $(3.811 \pm 0.254 \mathrm{~g} / \mathrm{dl})$ and albumin $(2.029 \pm 0.165 \mathrm{~g} / \mathrm{dl})$ of cystic fluid showed a significant $(\mathrm{p}<0.05)$ increase in concentration

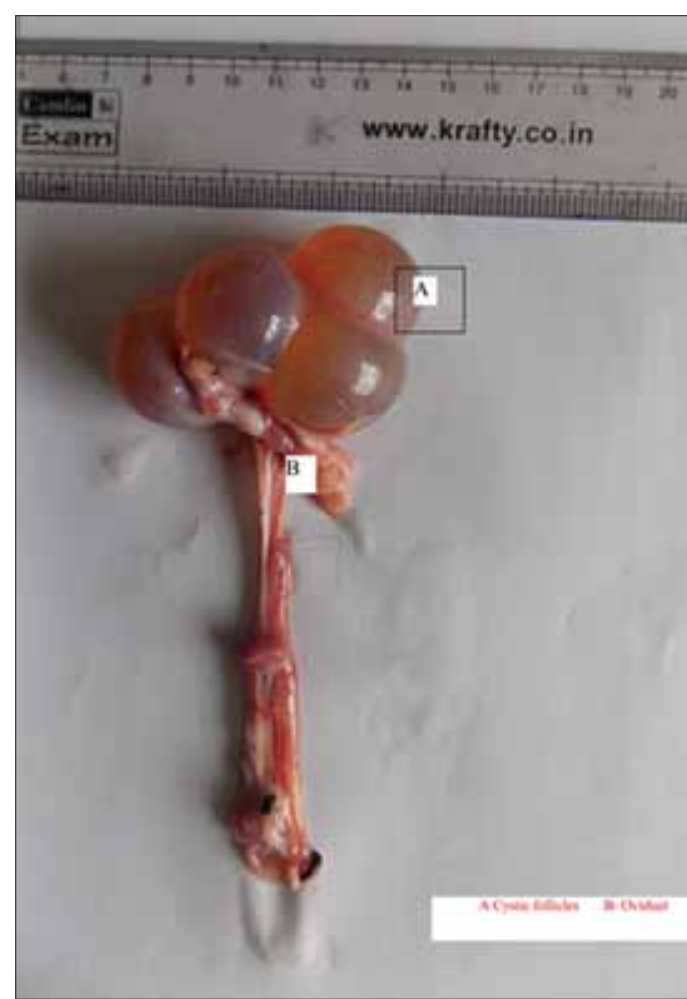

Figure-1: Cystic ovary of sow, (a) Cystic follicles, (b) Oviduct.

Table-1: Mean values $( \pm \mathrm{SE})$ of various biochemical metabolites of follicular fluid of sow.

\begin{tabular}{lcc}
\hline Parameters & $\begin{array}{c}\text { Normal follicles } \\
\text { (Group I) }\end{array}$ & $\begin{array}{c}\text { Cystic follicles } \\
\text { (Group II ) }\end{array}$ \\
\hline Glucose $(\mathrm{mg} / \mathrm{dl})$ & $35.871 \pm 1.876^{\mathrm{a}}$ & $58.492 \pm 2.245^{\mathrm{b}}$ \\
Total protein $(\mathrm{g} / \mathrm{dl})$ & $3.811 \pm 0.254^{\mathrm{a}}$ & $6.366 \pm 0.613^{\mathrm{b}}$ \\
Albumin $(\mathrm{g} / \mathrm{dl})$ & $2.029 \pm 0.165^{\mathrm{a}}$ & $4.034 \pm 0.224^{\mathrm{b}}$ \\
Globulin $(\mathrm{g} / \mathrm{dl})$ & $1.759 \pm 0.240^{\mathrm{a}}$ & $2.534 \pm 0.450^{\mathrm{a}}$ \\
A: G ratio & $1.585 \pm 0.283^{\mathrm{a}}$ & $2.440 \pm 0.396^{\mathrm{a}}$ \\
Glucose $(\mathrm{mg} / \mathrm{dl})$ & $58.837 \pm 2.395^{\mathrm{a}}$ & $58.849 \pm 2.396^{\mathrm{a}}$ \\
Cholesterol $(\mathrm{mg} / \mathrm{dl})$ & $39.116 \pm 1.715^{\mathrm{a}}$ & $88.404 \pm 7.638^{\mathrm{b}}$ \\
Triglyceride $(\mathrm{mg} / \mathrm{dl})$ & $33.144 \pm 1.349^{\mathrm{a}}$ & $91.042 \pm 6.307^{\mathrm{b}}$ \\
Urea $(\mathrm{mg} / \mathrm{dl})$ & $5.618 \pm 0.394^{\mathrm{a}}$ & $4.018 \pm 0.315^{\mathrm{a}}$ \\
BUN $(\mathrm{mg} / \mathrm{dl})$ & $2.505 \pm 0.176^{\mathrm{a}}$ & $1.792 \pm 0.140^{\mathrm{b}}$ \\
Uric acid $(\mathrm{mg} / \mathrm{dl})$ & $2.715 \pm 0.429^{\mathrm{a}}$ & $1.366 \pm 0.286^{\mathrm{a}}$ \\
Creatinine $(\mathrm{mg} / \mathrm{dl})$ & $1.222 \pm 0.194^{\mathrm{a}}$ & $1.673 \pm 0.334^{\mathrm{a}}$ \\
\hline Figures $\mathrm{With} \mathrm{dferent}$ &
\end{tabular}

Figures with different superscripts within row differ significantly $(p<0.05) . S E=S t a n d a r d$ error, $B U N=B l o o d$ urea nitrogen

Table-2: Mean values ( \pm SE) of different enzymatic activities of follicular fluid of sow.

\begin{tabular}{lcc}
\hline $\begin{array}{l}\text { Parameters } \\
\text { (U/ L) }\end{array}$ & $\begin{array}{c}\text { Normal follicles } \\
\text { ( Group I ) }\end{array}$ & $\begin{array}{c}\text { Cystic follicles } \\
\text { (Group I I ) }\end{array}$ \\
\hline AST & $136.353 \pm 7.244^{\mathrm{a}}$ & $140.741 \pm 6.964^{\mathrm{a}}$ \\
ALT & $127.764 \pm 7.938^{\mathrm{a}}$ & $409.198 \pm 72.295^{\mathrm{b}}$ \\
ALP & $418.152 \pm 47.009^{\mathrm{a}}$ & $715.872 \pm 111.325^{\mathrm{b}}$ \\
GGT & $10.624 \pm 0.574^{\mathrm{a}}$ & $6.400 \pm 0.713^{\mathrm{b}}$ \\
CK & $98.716 \pm 10.828^{\mathrm{a}}$ & $154.869 \pm 11.668^{\mathrm{b}}$ \\
\hline
\end{tabular}

Figures with different superscripts within row differ significantly $(p<0.05)$. ALT $=$ Aspartate transaminase, $\mathrm{ALT}=$ Alanine transaminase, ALP=Alkaline phosphatase, $\mathrm{CK}=$ Creatine kinase, $\mathrm{GGT}=$ Gamma-glutamyl transpeptidase

than the follicular fluid of preovulatory ovary. Cholesterol $(88.404 \pm 7.638 \mathrm{mg} / \mathrm{dl})$ and triglyceride $(91.042 \pm 6.307 \mathrm{mg} / \mathrm{dl})$ also showed a significant 
$(p<0.05)$ increase in concentration in the cystic fluid, but BUN $(1.792 \pm 0.140 \mathrm{mg} / \mathrm{dl})$ decreased significantly $(\mathrm{p}<0.05)$. The enzyme activities of ALT, ALP and CK showed a significant $(\mathrm{p}<0.05)$ increase in the cystic fluid from $127.764 \pm 7.938,418.152 \pm 47.009$ and $98.716 \pm 10.828 \mathrm{IU}$ to $409.198 \pm 72.295,715.872 \pm 111.325$ and $154.869 \pm 11.668 \mathrm{IU}$, respectively. The activity of GGT significantly $(\mathrm{p}<0.05)$ decreased from $10.624 \pm 0.574$ to $6.400 \pm 0.713 \mathrm{IU}$.

\section{Discussion}

Cystic ovarian disease (COD) has been a concern for producers and veterinarians for almost two centuries because a diagnosis of COD usually means the cow is not pregnant [6]. A German scientist in 1831 [7] wrote one of the earliest records of COD noting its relationship to infertility. Reproductive acyclicity has been associated with alterations in biochemical and hormonal composition of follicular fluid microenvironment $[6,8]$. Contraction of the theca externa layer of the wall of the preovulatory follicle is one of the main factors involved in the rapture and thus the ovulation. An alternation to this mechanism may lead to an inefficacious contraction of the smooth muscle fibres of the follicular wall and consequently to the development of the follicular cyst [9]. Previous workers $[10,11]$ also observed a significant $(p<0.05)$ increase in protein and albumin concentration in the cystic follicular fluid of cattle. Maniwa et al. [3] designed a special study to identify the specific proteins in the follicular fluid of bovine ovarian follicular cyst (BOFC) in order to clarify the pathology of BOFC using 2-D PAGE. They found eight additional protein spots on the gel from the cystic follicles compared with the normal control, and these proteins were identified as bovine mitochondrial f1-atpase, erythroid associated factor, methionine synthase, vascular endothelial growth factor-receptor, glyceraldehydes 3 -phosphate dehydrogenase, heat shock protein 70 , $\beta$-lactoglobulin and succinate dehydrogenase Ip subunit (SD) using the matrix assisted laser desorption ionization time-of-flight technique. Since these proteins are over expressed in BOFC, the total protein concentration increased in our study. Hassanin [12] also observed a significant $(\mathrm{p}<0.05)$ increase in total protein concentration in the cystic fluid. The results of the present study are in line with the previous reports [13,14]. They also reported an increase in cholesterol and triglyceride The increase in cholesterol content of cystic fluid could be attributed to the production of steroid, which depends on the supply of cholesterol from intracellular de novo synthesis, deesterification of intracellular stored cholesterol ester or uptake from lipoprotein bound cholesterol $[13,15]$. On the other hand, the high triglyceride concentration in cystic follicles may be the alternate sources of energy for the cells in the follicles [16]. Glucose is the crucial energy substrate for ovarian activity and in the cystic follicle the glucose concentration increased significantly $(\mathrm{p}<0.05)$. This is because the cystic follicles have the ability to filter and reserve the high concentrations of glucose from the blood for utilization in their development [16]. A further reason for this observation could be the increased permeability of the blood-follicle barrier during follicular growth [17].

\section{Conclusion}

Thus from the study, it can be concluded that cystic follicular fluid have an altered concentration of certain biochemical constituents in comparison to the preovulatory ovarian follicular fluid which indicates that the normal physiology of the affected animal is disturbed.

\section{Authors' Contributions}

RN, NM and MI planned and designed the study. NM and MI collected the samples, RN and SSD performed the biochemical tests and RN analyzed the data. All authors participated in draft and revision of the manuscript. All authors read and approved the final manuscript.

\section{Acknowledgments}

The authors are thankful to the Dean, Faculty Veterinary Science, AAU, Khanapara for providing necessary laboratory facilities to carry out the research work smoothly. The source of fund was departmental fund provided by Assam Agricultural university, Assam.

\section{Competing I nterests}

The authors declare that they have no competing interests.

\section{References}

1. Tal, R.B., Pen, S. and Roth, Z. (2009) Ovarian cyst in high yielding dairy cow. Theriogenology, 2: 690-698.

2. Gerard, N., Loiseau, S., Duchamp, G. and Seguin, G. F. (2002) Analysis of the variations of follicular fluid composition during follicular growth and maturation in the mare using proton nuclear magnetic resonance (1H NMR). Reproduction, 124: 241-248.

3. Maniwa, J., Izumi, S., Isobe, N. and Terada, T. (2005) Studies on substantially increased proteins in follicular fluid of bovine ovarian follicular cysts using 2-D PAGE and MALDITOF MS. Reprod. Biol. Endocrin., 3: 23.

4. Gode, F., Gulekli, B. Dogan, E., Korhan, P., Dogan, S., Bige, O., Cimrin, D. and Atabey, N. (2011) Influence of follicular fluid GDF9 and BMP15 on embryo quality. Fertil. Steril., 95: 2274-2278

5. Nath, R., Das, S., Sarma, S. and Devi, M. (2014) Comparison of blood profiles between healthy and Brucella affected cattle. Vet. World, 7(9): 668-670.

6. Khan, F.A., Das, G.K., Pande, M., Mir, R.A. and Shankar, U. (2011) Changes in biochemical composition of follicular fluid during reproductive acyclicity in water buffalo (Bubalus bubalis). Anim. Reprod. Sci., 127: 38-42.

7. Garm, O. (1949) A study on bovine nymphomania with special reference to etiology and pathogenesis. Acta Endocrinol., 3: 1-141.

8. Khan, F.A. and Das, G.K. (2012) Follicular characteristics and intrafollicular concentrations of nitric oxide and ascorbic acid during ovarian acyclicity in water buffalo (Bubalus bubalis). Trop. Anim. Health Prod., 44: 125-131. 
9. Rizzo, A., Cosala, S. and Sciorsci, R.L. (2010) Bovarian ovarian follicular cyst in vitro effecys of lecirilin, a GnRH analogue. Theriogenology, 74: 1559-1569.

10. Zeitoun, M.M. (2012) Effect of physiological status of buffalo ovaries on progesterone and biochemical constituents in follicular fluids. Proceedings of the 26th Annual Meeting of the Brazilian Embryo Technology Society (SBTE), Egypt.

11. Cynthia, J. and Johnson, M.S. (2006) Cystic ovarian disease in cattle on dairies in central and Western Ohio: Ultrasonic, hormonal, histologic, and metabolic assessments. Thesis Submitted to School of the Ohio State University.

12. Hassanin, K.D. (2007) Biochemical and hormonal changes in the follicular fluid in case of cystic ovarian diseases in cows. Res. Appl. Act., 54: 98-95.

13. Ahmed, W.H., Shalaby, S.I.A. and Zaabal, M.M. (1997) Some biochemical constituents of preovulatory and cystic ovarian follicular fluids in buffalo cows with emphasis on protein polymorphism. Buffalo Bull., 16(1): 5-10.

14. Carona, F.F.N., Olssan, J.H. and Hillensjo, T. (1983) Lipids, lipoprotein and steroids in serum and in fluid from stimulated and non - Stimulated human ovarian follicule. Endocrinology, 111: 558-562.

15. Kalmath, G.P. and Ravindra, J.P. (2007) Mineral profiles of ovarian antral follicular fluid in buffaloes during follicular development. Indian. J. Anim. Res., 41(2): 87-93.

16. Abd Ellah, M.R., Hussein, H.A. and Derar, D.R. (2010) Ovarian follicular fluid constituents in relation to stage of estrus cycle and size of the follicle in buffalo. Vet. World, 3(6): 263-267.

17. Albomohsen, H., Mamouei, M., Tabatabaei, S. and Fayazi, J. (2011) Metabolite composition variations of follicular fluid and blood serum in Iranian dromedary camels during the peak breeding season. J. Anim. Vet. Adv., 10(3):327-331.

$* * * * * * * *$ 